\title{
Sidorova T.A. \\ The German Historical School in the British Historiography of the Critical Trend. The End of the XIX-th - the First Half of the XX-th Centuries
}

Sochi Institute (affiliated branch) of Peoples' Friendship University of Russia

(Russia, Sochi)

doi: $10.18411 / g d s n-25-12-2019-34$

idsp: scienceconf-25-12-2019-34

\section{Abstract}

The article deals with analyses of the influence of the German historical school on the British historiography of the critical trend, also called in Europe "the law school". Chronological boundaries of the study - the end of the XIX-th - the first half of the XX-th centuries. The author examines the theoretical adoptions of the German scholars by the historians and lawyers of the British critical trend in their studies of Medieval England in the fields of history, law, economics, politics, social life. These adoptions had been critically revised in the British historiography and used for the growth of the national history of law.

Keywords: F.W. Maitland, the German historical school, the method of critical analyses, historical jurisprudence, the theory of corporation, "the corporation sole", the idea of law in history, "persona ficta", the burgh theory, hermeneutic approach, primary sources, the British historiography of the critical trend (law school), studies on Medieval England.

The British historiography of the critical trend of the end of the XIX-th the first half of the XX-th centuries (law school) was greatly influenced by the German historical school in a broad sense, including the German historical school of law and the German philosophical / legal hermeneutics. At the turn of the XIX-th and the XX-th centuries the theoretical jurisprudence in Great Britain was still in its infancy as well as the history of English law, which growth needed the reliable theoretical foundations. The "great Germans" became the teachers of the English historians and lawyers, who were the source of the problem and contributed to its formation and development. The British historians of the critical trend - A. Ballard, M. Bateson, N.S.B. Gras, H.L. Gray, F.G. Davenport, D.C. Douglas, E. Jenks, J.E. Jolliffe, H. Cam, A.E. Levett, W.Sh. McKechnie, T.F.T. Plucknett, A.F. Pollard, F.M. Powicke, H.G. Richardson, F.M. Stenton, G.O. Sayles - followed F.W. Maitland, their leader, who deeply studied the German historical, philosophical and juristic legacy and widely used it in his works on the English Medieval history.

The works of B.G. Niebuhr, L. von Ranke, H. Brunner, O.F. von Gierke, A. Meizen, F.W.E. Keutgen, F.C. von Savigny, R. Sohm, G.L von Maurer armed the British historians of the critical trend with advanced ideas, theories and methods of scientific research. They played a huge role in shaping their historical views and formation of theoretical and methodological basis of their scientific studies. The ideas of the "great Germans" in the fields of history, law, economics, politics, social life have become a source of their reflection on the state of their own historical and legal science, studies, critics and scholarly debates.

"The critical" historical and law concept of F.W. Maitland (1850-1906), the founder and the greatest historian of the critical trend in England, was based on its fundamental research method - the method of critical analyses, which he adopted from B.G. Niebuhr and L. Ranke. The most important characteristics of this method as the following: appeal to a reliable source of evidence, its authenticity, comparative and critical examination of historical texts and law records, objectivity in the study of history, personal work of the historian in the archives in order to get the evidence from primary sources $[17, \mathrm{p} .83]$.

But, this method in F.W. Maitland's studies of the Medieval English history was not reduced to mechanical reception of work with legal texts. Due to his skill the critical method was raised to a level of philosophy of creativity: on the critical method rested the conviction of the historian in the possibility of an objective restoration of the historical past based on historical 
evidences. He believed that by this method "the darkest ages" of the English history of law, studied retrospectively, could be reconstructed.

F.W. Maitland was one of the central figures, a "towering figure" [19, p. 322], who helped to turn the study of history in Britain into a professional pursuit, in which the scholar was encouraged to spend long hours in the archives reading primary sources, in order to produce thoroughly researched works on specific periods and subjects. This very Germanic method stood in contrast to the tradition of gentlemanly historiography in England, written by men such as E.A. Freeman, whose passion for the grand narrative matched their aversion for the archives [6, p. 4].

In the works of the German legal scholars F.W. Maitland was interested in the theoretical problems of historical jurisprudence. Much he learned from O. Gierke to the understanding of whose complex writings he came quite late, not before the 1890-s, when he together with F. Pollock worked on "The History of English Law". Under the impression of O. Gierke's "Das Deutsche Gennossenschaftsrecht" [3] F.W. Maitland reworked the section about the medieval boroughs to the second addition of "The History of English Law". He then started the translation into English the O. Gierke's "Political Theories of the Middle Ages" [10], which he did with all his skill and knowledge. O. Gierke, as G.P. Gooch wrote, called F.W. Maitland "the inspired interpreter" of his ideas and colleague in learning of the issues of corporate [4, p. 372].

Earlier F.W. Maitland began the translation, never completed, of the famous work of the German legal historian F.K. Savigny "Geschichte des Römisshen Rechts im Mittelalter" and hoped to be able to do for English law what Savigny had done for Roman law [14; 18, p. 9].

In the translation process F.W. Maitland faced difficulties of a linguistic and semantic nature: there were no definitions in English which could adequately convey the meaning of European, German and Latin, special legal terminology - "Recht", "Aktiengesellschaft, "Gesellschaft", "Gesellschaftsvertrag", "Staat", "Genossenschaftstheorie", "Gesammtperson", "Gesammtwille", "Korperschaftsbegriff", "Korporationstheorie", "persona ficta", etc. [10, p. XXI-XXVI]. That was a sign of undeniable backwardness of British theoretical jurisprudence. So F.W. Maitland had to invent new words and phrases to make O. Gierke's "Political Theories of the Middle Ages" clear to the English. He highly evaluated the German theory of corporation: "The new theory was to be philosophically true, scientifically sound, morally righteous, legally implicit in codes and decisions, practically convenient, historically destined, genuinely German, and perhaps exclusively Germanistic" [10, p. XXV].

Moreover, F.W. Maitland was the first in the British medieval studies who start to learn the English-French language of the XIV-th century and wrote the special grammar essay, highly appreciated by the most authoritative European experts [15, c. 86, 95]. F.W. Maitland was a pioneer in historical semantics.

The Russian historians P. Vinogradoff and A. Savin believed that O. Gierke mostly influenced on F.W. Maitland of all the German historians and jurists [15, p. 106; 20, p. 288]. But as far as I understand, it was F.K. Savigny from whom F.W. Maitland firstly adopted the leading role of the idea of law in history and the history of law, that law was the product of the spirit of the nation, has a historical origin, could be comprehended historically and should be studied historically, within the historical context. It was the direct effect of the German historical school, the brightest representative of which was F.K. Savigny. However, F.W. Maitland did not aim to use history to advance jurisprudence, he was famously sceptical about the utility of history to lawyers, he dismissed the approach of the "historical school now fashionable", which said that property law was a product of social evolution and national life, as M. Lobban, Professor of Legal History, rightly wrote [6, p. 6]. But I should say that these concerned F.W. Maitland's attitude to anachronism - the research approach then widely spread then in British historiography, which he considered unhistorical. This was not the case for the German historical school as a whole.

F.K. Savigny aroused F.W. Maitland's interest in the study of legal fiction, "persona ficta", dating back to Roman law, used in Roman law and in Middle ages. Then he came to O.F. 
Gierke's theory of the Corporation, which had been critically reworked and used by him to explain the complex status of the British Crown based on the concept of "corporation sole" [7].

The influence of the German school in F.W. Maitland's works had reflected on his understanding of the essence of feudalism. As O.F. Gierke, he perceived feudalism as a complex political and legal system with a branched hierarchy of the land relations where the contract of private law prevailed [3, bd. 1, s. 153]. He shared the views of $\mathrm{H}$. Brunner on the need to study legal habits and institutions of law within the historical context, not isolated of it [2, bd. 1, s. 6]. F.W. Maitland was in solidarity with G.L Maurer and A. Meizen on the issue of the existence of community relations of all Germanic tribes since the ancient times, the preservation of the community for a long time after the establishment of feudalism and that the community was more earlier institute than manor [11, s. 96; 12, bd. 1; 13, vol. I, p. 564-566, 615]. F. Keutgen's burgh theory of the origin of the boroughs F.W. Maitland considered universal and applying it on the English soil, developed its analogue - the garrison theory to explain the rise of boroughs in Medieval Britain [5; 8; 9].

Briefly, about F.W. Maitland's hermeneutic approach to the study of the history of English law. I am not sure whether he knew directly the philosophical works of $F$. Schleiermacher, F. Schlegel, W. Dilthey, E. Husserl or came to hermeneutic methods on their own, subconsciously, but given his inexhaustible interest in German theoretical literature [20, p. 288], it cannot be excluded. For F.W. Maitland hermeneutics was of particular value in his intention to know the mental specifics of medieval people through the study of their law. In the social and philosophical essence the legal culture is the social phenomenon, the way of organizing and acting of the man by the legal norms, the laws, the level of civility. From this point of view, hermeneutics especially closely related to law. The legal hermeneutics is essentially historical, because it implies thinking on legal texts and social facts learned on the basis of laws. This goal was pursued by F.W. Maitland.

The difficulty of the historian's task was to express another time in its realities, conveying it in the language of concepts of his own time [1, p. 72]. Hermeneutics was the perfect way to achieve this goal thanks to one of its most important categories - the time interval. Much of what did the founding fathers understood by hermeneutics, was manifested in the work of F.W. Maitland. F. Schleiermacher believed that the understanding of someone else's text requires genius - F.W. Maitland was a genius, and the contemporaries recognized this. According to W. Dilthey, the main way of knowledge of the social sphere was the spiritual dialogue with the person of the studied epoch - in the laws of Medieval England F.W. Maitland saw the way of legal understanding of social reality, the history, which he tried to comprehend by mental categories of the Middle Ages. E. Husserl gave hermeneutics the ability to interpret the spiritual life of particular person and his world - F.W. Maitland tried to reconstruct the social history of English Middle ages through its legal mentality [17, p. 99-101].

F.W. Maitland's theoretical adoptions were not the blind copying or repetition of the achievements of the German historians. For he, as A.N. Savin rightly pointed out, was much stronger in analysis than in synthesis, therefore all theoretical adoptions brought him the great benefit [16, p. 442-443].

In the first half of the twentieth century, F.W. Maitland's work inspired a succeeding generation of historians, not lawyers, who were interested in law as one of the means of governance in medieval society: H.G. Richardson (1884-1974), G.O. Sayles (1901-94), H. Cam (1885-1968), Sir Frank (1880-1967) and Doris Stenton (1894-1971). They were the historians trained by universities which by the 1920-s were beginning to imitate the German idea that history was a subject to be studied scientifically, based on extensive research into primary sources. Their work contributed importantly to an enriching of the medieval historiography of law, in the editions and monographs they produced. T.F.T. Plucknett was a historian, rather than a lawyer by training, and his scholarship displayed many of the characteristics of Maitland's highly focused archival methods [6, p. 7-8]. 
The German Historical School in a broad sense, including the German historical school of law and the German philosophical / legal hermeneutics, had greatly influenced the British historiography of the critical trend (law school) of the end of the XIX-th - the first half of the XX-th centuries. The British historians F.W. Maitland, especially, A. Ballard, M. Bateson, N.S.B. Gras, H.L. Gray, F.G. Davenport, D.C. Douglas, E. Jenks, J.E. Jolliffe, H. Cam, A.E. Levett, W.Sh. McKechnie, T.F.T. Plucknett, A.F. Pollard, F.M. Powicke, H.G. Richardson, F.M. Stenton, G.O. Sayles - needed the reliable theoretical foundations for the growth of the national history of law, which was their research subject.

From the works of the "great Germans" - B.G. Niebuhr, L. von Ranke, H. Brunner, O.F. von Gierke, A. Meizen, F.W.E. Keutgen, F.C. von Savigny, R. Sohm, G.L von Maurer - they adopted, critically revised and widely used the method of critical analyses, the theory of corporation, "persona ficta", the idea of law in history, the hermeneutic approach, the burgh theory. The British reflected the German idea that history was a subject to be studied scientifically, based on extensive research into primary sources. Due to the German historical school, the British historiography of the critical trend was enriched with knowledge, which raised it to the level of European science.

$$
* * *
$$

1. Barg M.A. «Historical Time»: Methodological Aspect // Modern and Contemporary History. 1990. No. 1.

2. Brunner H. Deutsche Rechtsgeschuchte. 2. Aufl. - Leipzig, 1906.

3. Gierke O. Das Deutsche Gennossenschaftsrecht. - Berlin, 1868-1913. 4 vols.

4. Gooch G. P. History and Historians in the Nineteenth Century. - London, New York, 1913. -600 p.

5. Keutgen F. W.E. Untersuchungen uber der Ursprung der Deutschen Stadtverfassung. - Leipzig, 1895.

6. Lobban M. The Varieties of Legal History // Clio Themis. No. 5, 2012, pp. 1-29.

7. Maitland F.W. The Crown as Corporation // The Law Quarterly Review. 1901. No. 17, pp. 131-146.

8. Maitland F. W. Domesday Book and Beyond: Three Essays in the Early History of England. - Cambridge, 1897. $-548 \mathrm{p}$.

9. Maitland F. W. Township and Borough: The Ford Lectures. - Cambridge, 1898. - 220 p.

10. Maitland F. W. Political Theories of the Middle Ages, by Dr. Otto Gierke. Translated with an Introduction, by F. W. Maitland. - Cambridge, 1900. - 197 p.

11. Maurer G.L. von. Einleitung zur Geschichte der Markt-, Hof-, Dorf- und Stadtverfassung und der Offentlichen Gewalt. - München, 1854.

12. Meizen A. Siedelung und Agrarwesen der Westgermanen und Ostgermanen, der Keiten, Römen, Finnen und Slaven. - Berlin, 1895. Bd. I.

13. Pollock F. and Maitland F.W. The History of English Law before the Time of Edward I. - Cambridge, 1923. Vol. I- II.

14. Savigny F.K. Geschichte des Römischen Rechts in Mittelalter. Bd. 1-2. - Heidelberg, 1815.

15. Savin A.N. In Memory of Maitland // The Russian thought. B. 10, 1907, pp. 80-106.

16. Savin A.N. The English Lawyer in the Role of Historian // The Journal of the Ministry of National Enlightenment, 1900. No. 12, pp. 442-443.

17. Sidorova T.A. Frederic William Maitland and British Historiography of the Critical Trend. The End of the XIX-th - the First Half of the XX-th Century. - Saint-Petersburg: "Aletheia", 2014. - 696 p. (Pax Britannica).

18. Schuyler. R.L. Frederic William Maitland, Historian. Selections from his Writings. - The University of California Press, 1960. - 261 p.

19. Schuyler R.L. The Historical Spirit Incarnate: Frederic William Maitland // The American Historical Review, Vol. 57, No. 2, January, 1952, pp. 303-322.

20. Vinogradoff P. Frederic William Maitland // The English Historical Review. 1907. April. Vol. XXII. No. LXXXV, pp. 280-289. 